\title{
A comprehensive evaluation of competitiveness of China's Listed Commercial
} Banks

\author{
Zhu Jinghu ${ }^{\mathrm{a}}$, Qu Yi ${ }^{\mathrm{b}}$, Zhao Fengying \\ Harbin Vocational College of Science and Technology, Harbin, China, 150300 \\ åEmail: ZhuJinghu@hrbkjzy.com; ㄹEmail: 26444806@qq.com; ㅌEmail: ZhaoFengying@hrbkjzy.com
}

Keywords: Commercial bank; Competitiveness; Factor analysis

\begin{abstract}
Due to the rapid development of Internet banking in the world, the traditional sense of the commercial banks has been greatly hampered in business. So China should pay more attention to the comprehensive competitiveness of commercial banks. Based on this, this paper extends from the meaning of the competitiveness to the competitiveness of the bank, the bank competitiveness theory about academic exchange score analysis. In this paper, 24 listed commercial banks are selected as the research object, and a relatively perfect competitiveness evaluation system of commercial banks is constructed by using 14 indexes in five aspects, such as asset security, capital flow and profitability, and the overall competitiveness of the listed commercial banks is analyzed and evaluated by means of factor analysis and rotation matrix.
\end{abstract}

\section{Introduction}

In 2007, the United States had a huge impact of the subprime mortgage crisis, in the world wide expansion, to the world economy has brought not only to ignore the impact, but also make our country's economy fall into a state of decline, China's listed commercial banks in this process also deep in the process of its harm. By 2015, the world's economic situation has not been greatly improved, the economic situation is still unpredictable, the world economy is still in a profound rebalance adjustment period, different countries and economies have different development trends, and their macro policies are disproportionate with the economic situation, making the developed countries not in the crisis. The economic recovery of the developing countries is relatively slow, but the state of economic performance in our country is relatively stable in the whole, but the trend of global economic integration is constantly developing, the process of financial integration is constantly promoted, the foreign banks in our country are more and more, the foreign banks are to our banking industry. The influence is increasing. In this situation, how to achieve rapid development of Chinese listed commercial banks and how to improve the external environment of the financial industry is a crucial topic. Therefore, it is imminent to promote the competitiveness of China's commercial banks with a purpose.

\section{Model Construction}

\subsection{Evaluation index system.}

The basic attributes of commercial banks are enterprises. Enterprises need to improve business models, increase business varieties, improve service quality to meet the needs of more customers, occupy the market, and maximize profits. The commercial bank is a special enterprise. Compared with the general enterprise, the main business object of the bank is the currency, the main assets and liabilities business, and the bank is also special in its own core capital is low, the asset liability rate is very high, therefore, the bank has a great risk in the course of operation. Banks should expand their market share and realize their own profits at the same time of realizing their three operating principles "profitability, liquidity and safety". Commercial banks also undertake social responsibilities, and 
cooperate with the people's Bank of China and the government to maintain financial order, stabilize macroeconomic environment and promote steady economic growth.

According to the above characteristics of commercial banks, this paper analyzes the competitiveness of banks from five aspects: profitability, liquidity, security, market occupancy and growth. For example, table 1.

Table 1 Evaluation index system

\begin{tabular}{|c|c|c|c|}
\hline & number & Index name & Calculation formula \\
\hline \multirow{3}{*}{ Profitability index } & $\mathrm{X} 1$ & asset return & net profit / assets \\
\hline & $\mathrm{X} 2$ & capital return & net profit / shareholders' equity \\
\hline & X3 & earnings per share & net profit / total equity \\
\hline \multirow{3}{*}{ Liquidity index } & $\mathrm{X} 4$ & deposit loan ratio & loan / deposit total \\
\hline & X5 & property right ratio & liability / shareholders' equity \\
\hline & X6 & asset liability ratio & liabilities / assets \\
\hline \multirow{3}{*}{ Safety index } & $\mathrm{X7}$ & core capital adequacy ratio & core capital / risk weighted \\
\hline & $\mathrm{X} 8$ & bad loan rate & bad loan amount / loan balance \\
\hline & X9 & provision coverage & $\begin{array}{c}\text { loan loss reserve } \\
\text { /non-performing loan balance }\end{array}$ \\
\hline \multirow[t]{3}{*}{ Market share index } & $\mathrm{X} 10$ & deposit share & $\begin{array}{c}\text { total deposit / total market } \\
\text { deposit }\end{array}$ \\
\hline & $\mathrm{X} 11$ & loan share & total loan / market loans \\
\hline & $\mathrm{X} 12$ & asset share & $\begin{array}{c}\text { total assets / financial } \\
\text { institutions' total assets }\end{array}$ \\
\hline \multirow{4}{*}{ Growth indicators } & $\mathrm{X} 13$ & deposit growth rate & deposits growth / early deposits \\
\hline & $\mathrm{X} 14$ & loan growth rate & loan growth / early loan \\
\hline & X15 & capital accumulation rate & $\begin{array}{c}\text { shareholder equity growth / } \\
\text { shareholders' equity early }\end{array}$ \\
\hline & $\mathrm{X} 16$ & $\begin{array}{l}\text { fee and commission } \\
\text { income growth rate }\end{array}$ & $\begin{array}{l}\text { fee income growth / initial fee } \\
\text { income }\end{array}$ \\
\hline
\end{tabular}

\subsection{Empirical analysis}

First, KMO test and Bartlett test are carried out. From table 2, the value of KMO value is $0.528>0.5$ and the statistical value of Bartlett sphericity test is 624.488 , and the significant probability sig. is 0 . It shows that the sample data has correlation, and the condition is suitable for factor analysis.

Table 2 KMO and Bartlett test

\begin{tabular}{llr}
\hline \multicolumn{3}{c}{ KMO and Bartlett test } \\
\hline KMO sample appropriateness & .528 \\
Bartlett sphericity & Approximate chi & 624.488 \\
test & square & \\
& Freedom & 120 \\
& Saliency & .000 \\
\hline
\end{tabular}

According to the common factor that the cumulative contribution rate of the factor exceeds $80 \%$, this paper selects four common factors, that is, it can reflect most of the information of the original data. 
Table 3 component score coefficient matrix

\begin{tabular}{lcccc}
\hline \multicolumn{5}{c}{ component } \\
\hline VAR00001 & 1 & 2 & 3 & 4 \\
VAR00002 & -.040 & .279 & .044 & -.217 \\
VAR00003 & .042 & .235 & .231 & -.264 \\
VAR00003 & .083 & .046 & .192 & .111 \\
VAR00004 & -.084 & .046 & .192 & .111 \\
VAR00005 & .099 & -.139 & .180 & .134 \\
VAR00006 & .100 & -.037 & .284 & .000 \\
VAR00007 & -.095 & -.020 & .293 & .050 \\
VAR00008 & -.091 & .080 & -.257 & -.156 \\
VAR00009 & .107 & .002 & .066 & -.295 \\
VAR00010 & -.101 & .186 & -.186 & .241 \\
VAR00011 & -.103 & .183 & .074 & .248 \\
VAR00012 & -.101 & .183 & .073 & .248 \\
VAR00013 & .104 & .142 & .089 & .262 \\
VAR00014 & .108 & .099 & -.158 & -.111 \\
VAR00015 & .110 & .108 & -.126 & .239 \\
VAR00016 & .101 & .117 & -.076 & .255 \\
\hline
\end{tabular}

According to the matrix of component score coefficient of table 4.7, the score of each factor can be constructed by taking the score of each factor on each observation variable as a coefficient.

The factor score function is:

$$
\mathrm{Fj}=\beta \mathrm{j} 1 \mathrm{X} 1+\beta \mathrm{j} 2 \mathrm{X} 2+\ldots+\beta \mathrm{jpXp}
$$

From the above formula, we can get the scoring formula of each factor.

$$
\begin{gathered}
\mathrm{F} 1=-0.04 \mathrm{X} 1+0.042 \mathrm{X} 2+0.083 \mathrm{X} 3-0.084 \mathrm{X} 4+0.099 \times 5+0.1 \mathrm{X} 6-0.095 \mathrm{X} 7-0.091 \mathrm{X} 8+0.107 \mathrm{X} 9-0.101 \mathrm{X} 10- \\
0.103 \mathrm{X} 11-0.101 \mathrm{X} 12+0.104 \mathrm{X} 13+0.108 \mathrm{X} 14+0.110 \mathrm{X} 15+0.101 \mathrm{X} 16
\end{gathered}
$$

$\mathrm{F} 2=0.279 \mathrm{X} 1+0.235 \mathrm{X} 2+0.046 \mathrm{X} 3-0.139 \mathrm{X} 4-0.037 \mathrm{X} 5-0.02 \mathrm{X} 6+0.08 \mathrm{X} 7+0.002 \mathrm{X} 8+0.058 \mathrm{X} 9+0.186 \mathrm{X} 1$ $0+0.183 \mathrm{X} 11+0.183 \mathrm{X} 12+0.142 \mathrm{X} 13+0.099 \mathrm{X} 14+0.108 \mathrm{X} 15+0.117 \mathrm{X} 16$

$$
\begin{gathered}
\mathrm{F} 3=0.044 \mathrm{X} 1+0.231 \mathrm{X} 2+0.192 \mathrm{X} 3+0.180 \mathrm{X} 4+0.284 \mathrm{X} 5+0.293 \mathrm{X} 6-0.257 \mathrm{X} 7+0.066 \mathrm{X} 8-0.186 \mathrm{X} 9+0.074 \\
\mathrm{X} 10+0.073 \mathrm{X} 11+0.089 \mathrm{X} 12-0.158 \mathrm{X} 13-0.126 \mathrm{X} 14-0.076 \mathrm{X} 15-0.021 \mathrm{X} 16
\end{gathered}
$$

\section{$\mathrm{F} 4=-0.217 \mathrm{X} 1-0.264 \mathrm{X} 2+0.111 \mathrm{X} 3+0.134 \mathrm{X} 4+0.05 \mathrm{X} 6-0.156 \mathrm{X} 7-0.295 \times 8+0.241 \mathrm{X} 9+0.248 \mathrm{X} 10+0.248$ $\mathrm{X} 11+0.262 \mathrm{X} 12-0.111 \mathrm{X} 13+0.239 \mathrm{X} 14+0.255 \mathrm{X} 15-330 \mathrm{X} 16$}

According to the above model, the score of each factor can be obtained, and then the weighted sum of the variance contribution rate corresponding to the components of each factor is weighted to get the comprehensive evaluation score of 24 commercial banks, that is, F.

$$
\mathrm{F}=0.5173 \mathrm{~F} 1+0.2267 \mathrm{~F} 2+0.1588 \mathrm{~F} 3+0.0971 \mathrm{~F} 4
$$

From the perspective of growth factor analysis, it can be seen from table 4that urban commercial banks are most outstanding in terms of growth factors. Among the seven city commercial banks, Nanjing bank, Guiyang bank, Ningbo bank, Jiangsu bank and Beijing bank are the first to fifth respectively. In the joint-stock banks, the growth of Xingye Bank ranked the sixth best. But the five state-owned large commercial banks are ranked in the rear, and the Bank of communications ranks 18, while the Agricultural Bank, the Bank of China, the Construction Bank and the industrial and commercial bank are ranked the four. From the profitability factor analysis, the ICBC, China Construction Bank, China Agricultural Bank and Bank of China, which reflect the profitability 
factors of the commercial banks, have the top ranks, but the Bank of Guiyang ranks first, the Guiyang bank's asset return rate is $1.36 \%$ and the asset return rate is $23.22 \%$, which is the highest in the 24 banks. It can be seen that the Bank of Guiyang is very profitable. From the liquidity factor analysis, from the liquidity factor of each bank, joint-stock banks have outstanding performance. China bank, Pufa Bank and Xingye Bank are in the top three, which shows that the liquidity of the three are very strong.

\section{Conclusion}

This paper makes an empirical study on 24 listed commercial banks through SPSS software, and draws four public factors (growth factor, profitability factor, liquidity factor and scale, security factor) to analyze the competitiveness of banks, and rank commercial banks from four angles and comprehensive ability. To get different results, from the perspective of growth, the urban commercial banks have shown outstanding performance in all banks, have a very high growth and have an objective development prospect, while the large state-owned commercial banks have poor development potential. From the profitability analysis, the large state-owned commercial banks have shown good performance, and the profitability of the rural commercial banks is poor. From the perspective of liquidity, the liquidity of the stock banks is stronger in all kinds of banks. Under the effect of variance contribution, the overall performance of urban commercial banks is the most dependent. Before, the Nanjing bank is the first place, indicating that the city commercial banks will have a rapid development in the next few years. The joint-stock banks are in good performance and are in the middle and upper levels. The large state-owned commercial banks are poor in performance and are backward in their ranking, but they do not pay much attention to their innovation and reform, resulting in the synthesis of the commercial banks. Competitiveness is very low, and rural commercial banks are ranked behind because of limited business scope and low market share.

\section{Acknowledgements}

Heilongjiang Province ordinary undergraduate colleges and universities young innovative talents training plan. Research on the allocation efficiency of financial resources in China from the perspective of contract theory (item number: UNPYSCT-2016058), host Zhong Shen.

Heilongjiang Education Science 12th Five-Year plan topic. Research on "effective training of skilled talents in Higher Vocational Colleges" (item number: ZJC1215003), host Qu Yi

Study on the Countermeasures of Vocational Education Collectivization - Taking Harbin Modern Service Vocational Education Group as an example numbering the planning subject of the Provincial Education Department of the "13th Five-Year" program of education science of Heilongjiang Province. (Item number: ZJC1316055), host Zhu Jinghu.

\section{References}

[1] Colleen Pantalone, Marjorie Platt. Predicting commercial bank failure since deregulation [J].Journal of New England Economic Review, 2007(2):37-47

[2] Molyneux P. Competitive conditions in European banking [J].Journal of Banking and Finance, 2009(18):445-459

[3] Allen N.Berger, Robert De Young. Efficiency Barriers to the Consolidation of the European Financial Services Industry [J]. European Financial Management, 2011(1):117-130

[4] Ahmad. Measuring Islamic banks efficiency: the CaSO of world Islamic banking sectors [J].Journal of Islamic Banking and Finance, 2013(4):19-58

[5] Ahmad. Entry of foreign banks and their impact on host countries [J].Journal of Comparative Economics, 2014(36):430-452 